\title{
TOURISM IN CHINA: DESTINATIONS, PLANNING AND EXPERIENCES
}

Edited by C. Ryan and S. Huang. Channel View, Bristol, 2013, xx + 321 pages (figures, tables, index). £29.95 Pbk. ISBN: 978-1-84541400-9.

\section{Ralf Buckley}

Griffith University, Australia

Information flow between China and Anglophone research is asymmetric. Chinese universities republish English research, but the reverse is rare. This volume summarises Chinese PhD theses in tourism, expanding on Huang (2011), who followed Jafari and Aaser (1988). Every chapter has at least one Chinese author, though only half the authors currently live in mainland China. Two of the 19 chapters are rewrites of previous English journal articles. The others are new, or previously published in Chinese journals. A few use mathematical formulations, but most describe case-study sites, some also visited by international tourists. The collection is eclectic, but consistent factors do emerge. It seems to me there are four of these.

The first is cultural. Every country has its own culture, and many countries have multiple cultures associated with different regions or ethnic minorities. Such differences have been examined previously by a number of Chinese authors working collaboratively with Englishspeaking colleagues, such as Sofield and Li (1998) or Buckley, Ollenburg, and Zhong (2008) and Buckley, Zhong, Cater, and Chen (2008). These Chinese authors, however, do not cite this English-language literature at all comprehensively, so that aspect is not well presented.

The second is internal colonialism (p. 47). It appears that ethnic and religious minorities in China are now viewed by government agencies as tourism attractions, through their heritage buildings and cultural festivals. The minorities, however, are not entirely powerless. One of the chapters reports an ethnographic study, by a Han Chinese author, of a minority Tuva and Kazakh community. The Tuva leave their village houses in summer in order to graze cattle nomadically; but they lease their houses to Kazakh entrepreneurs, who pretend to be Tuva in order to attract tourists (p. 95). And at least one restaurant sells chickens at 20 times market value, by claiming they are wild jungle fowl caught in the forest (p. 96). 
The third is political. In China, guanxi, connections, are more powerful than legal rights or written contracts (p. 141). In a positive sense, guanxi are informal networks of mutual trust, widespread worldwide. In their negative form, however, guanxi include large-scale nepotism and political corruption. The editors argue that guanxi arose from the Confucian view that society was better governed by noble or moral men than by laws (p. 118). This only works, however, if those in power are upright. Currently, "Attracting tourism investment in less developed regions becomes a political tool for local officials to seek promotion” (p. 50). Officials force locals off landholdings through compulsory possession, and sell land and rights to developers in return for unmet promises of investment. "Provincial governments ... transfer the management rights of large tourist attractions ... to private or semi-private companies ... for personal gain" (p. 202). Compensation for relocated locals is inadequate and often unpaid. Employment opportunities are few and poorly paid, and generate community conflict. Such patterns occur elsewhere (Buckley, 2008); but are widespread in China.

The fourth is wealth. China has changed very greatly and rapidly over the past three decades. Individual wealth has grown, and the balance of power between individuals and state-owned corporations may also have shifted, albeit only slightly. When I visited China in 1983, tourism was effectively non-existent. Thirty years later in June 2013, a single local government brought a group of Australian tourism representatives to a meeting on marine ecotourism, to attract capital for six coastal resorts, and raised US\$22 billion from private Chinese investors in a single day.

The editors mention all four issues. They are too modest, perhaps, to draw the ultimate conclusion; so I will do it on their behalf. As tourism researchers, we can hardly claim to understand global tourism unless we have a good knowledge of China. This book is one step in that direction. 


\section{References}

Buckley, R. C. (2008). Misperceptions of climate change damage coastal tourism: case study of Byron Bay, Australia. Tourism Review International, 12(1), 71-88.

Buckley, R. C., Ollenburg, C., \& Zhong, L. S. (2008). Cultural landscape in Mongolian tourism. Annals of Tourism Research, 35(1), 47-61.

Buckley, R. C., Zhong, L. S., Cater, C., \& Chen, T. (2008). Shengtai luyou: cross-cultural comparison in ecotourism. Annals of Tourism Research, 35(4), 945-968.

Huang, S. (2011). Tourism as the subject of China's doctoral dissertations. Annals of Tourism Research, 38(1), 316-319.

Jafari, J., \& Aaser, D. (1988). Tourism as the subject of doctoral dissertations. Annals of Tourism Research, 15, 407-429.

Sofield, T. H. B., \& Li, F. M. S. (1998). Tourism development and cultural policies in China. Annals of Tourism Research, 25(2), 362-392. 